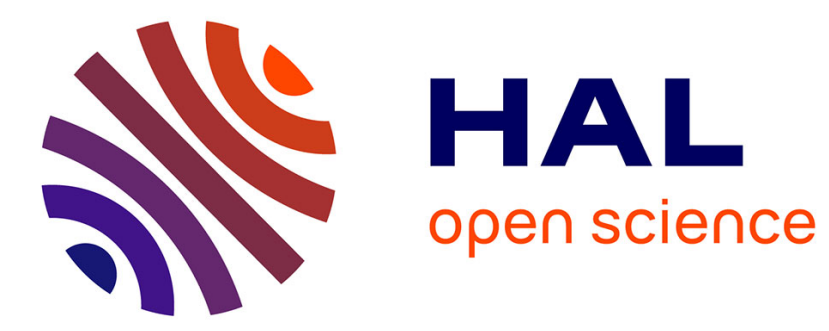

\title{
Reservoir Ages in the Western Tropical North Atlantic from One Coral off Martinique Island (Lesser Antilles)
} Martine Paterne, Nathalie Feuillet, Guy Cabioch, Elsa Cortijo, Dominique Blamart, Jennifer Weill-Accardo, Lucile Bonneau, Christophe Colin, Eric Douville, Edwige Pons-Branchu

\section{To cite this version:}

Martine Paterne, Nathalie Feuillet, Guy Cabioch, Elsa Cortijo, Dominique Blamart, et al.. Reservoir Ages in the Western Tropical North Atlantic from One Coral off Martinique Island (Lesser Antilles). Radiocarbon, 2018, 60 (2), pp.639 - 652. 10.1017/RDC.2017.118 . hal-01806834

\section{HAL Id: hal-01806834 https://hal.science/hal-01806834}

Submitted on 18 Jun 2021

HAL is a multi-disciplinary open access archive for the deposit and dissemination of scientific research documents, whether they are published or not. The documents may come from teaching and research institutions in France or abroad, or from public or private research centers.
L'archive ouverte pluridisciplinaire HAL, est destinée au dépôt et à la diffusion de documents scientifiques de niveau recherche, publiés ou non, émanant des établissements d'enseignement et de recherche français ou étrangers, des laboratoires publics ou privés. 


\title{
RESERVOIR AGES IN THE WESTERN TROPICAL NORTH ATLANTIC FROM ONE CORAL OFF MARTINIQUE ISLAND (LESSER ANTILLES)
}

\author{
Martine Paterne ${ }^{1 *} \cdot$ Nathalie Feuillet ${ }^{2} \cdot$ Guy Cabioch $^{3} \cdot$ Elsa Cortijo $^{1} \cdot$ Dominique Blamart $^{1} \cdot$ \\ Jennifer Weill-Accardo ${ }^{2,4} \cdot$ Lucile Bonneau $^{1,4} \cdot$ Christophe Colin $^{5} \cdot$ Eric Douville $^{1} \cdot$ \\ Edwige Pons-Branchu ${ }^{1}$

\footnotetext{
'Laboratoire des Sciences du Climat et de l'Environnement, LSCE/IPSL, CEA-CNRS-UVSQ, Université Paris-Saclay, Domaine du CNRS, F-91198 Gif-sur-Yvette, France.

${ }^{2}$ Institut de Physique du Globe de Paris, UMR 7154, CNRS Paris Sorbonne Paris Cité, Paris, France. ${ }^{3}$ IRD, Bondy, France.

${ }^{4}$ Earth Observatory of Singapore, Nanyang Technological University, 50 Nanyang Avenue, Singapore 639798. ${ }^{5}$ University of Heidelberg, Institute of Environmental Physics, Physics of Environmental Archives, Institute of Geosciences Neuenheimer Feld 234, 69120 Heidelberg, Germany.

${ }^{6}$ Laboratoire Geosciences Paris-Sud (GEOPS), Université de Paris Sud, Université Paris-Saclay, 91405 Orsay, France.
}

ABSTRACT. Sea surface reservoir ages (R) are reported from radiocarbon $\left({ }^{14} \mathrm{C}\right)$ measurements of the annual growth bands of coral Siderastrea siderea collected on the Atlantic coast off Martinique Island, in the Lesser Antilles volcan ic arc. Mean values of $\mathrm{R}$ are similar between 1835 and 1845 during pre-anthropogenic times at $385 \pm 30 \mathrm{yr}$ and between 1895 and 1905 at $382 \pm 20 \mathrm{yr}$ when there was a huge eruption from the Montagne Pelée volcano in 1902-1903. Limited ${ }^{14} \mathrm{C}$ aging of sea surface $(\sim 40 \mathrm{yr})$ may be due to enhanced volcanic activity. Variability of $\mathrm{R}$ is slightly greater during 1835-1845 than during 1895-1905. It is linked to a moderate increase of $\Delta^{14} \mathrm{C}$ of 5\%, strengthened by a clear increase of $\delta^{18} \mathrm{O}$ of $0.4 \%$. This is attributed to a decrease of the northward advection of the South Atlantic Waters into the western tropical North Atlantic and Caribbean Sea and relative enhanced westward flux of the tropical

North Atlantic surface waters, the southern waters having lower values of ${ }^{14} \mathrm{C}$ and $\delta{ }^{18} \mathrm{O}$ than the North Atlantic ones. From 1835 to 1845 , the fraction of the South Atlantic Waters transported up to Martinique Island was reduced from $25 \%$ to $15 \%$.

KEYWORDS: coral, Lesser Antilles, marine reservoir ages, Martinique, stable isotopes, volcanic effects.

\section{INTRODUCTION}

Quantification of the sea surface reservoir ages (R), a measure of the difference between the marine and atmospheric radiocarbon $\left({ }^{14} \mathrm{C}\right)$ ages at the same time, contributes substantially to a better understanding of ocean dynamics and climate. This difference is due to the isolation of subsurface seawater from the atmosphere and to ${ }^{14} \mathrm{C}$ decay. It reflects the balance between the ${ }^{14} \mathrm{C}$ production and the ocean-atmosphere exchange of ${ }^{14} \mathrm{CO}_{2}$ as well as mixing between the surface and subsurface waters by vertical convection and horizontal advection due to changes of wind strength and oceanic currents. Values of R can be measured from biogenic carbonates, the ${ }^{14} \mathrm{C}$ of which representing that of the dissolved inorganic carbon (DIC) in seawater in which they grow.

Numerous estimates of R from corals were obtained in the subtropical western North Atlantic (Druffel and Linick 1978; Druffel 1980, 1982, 1997; Druffel and Suess 1983; Goodkin et al. 2012; Fernandez et al. 2015), the Caribbean Sea (Druffel 1980; Druffel and Suess 1983; Guilderson et al. 2005; Kilbourne et al. 2007), and the Gulf of Mexico (Wagner et al. 2009). No values of $R$ were acquired within the Atlantic inflow, which penetrates into the eastern Caribbean Sea through the sill passages along the Lesser Antilles volcanic arc. Here we report values of $\mathrm{R}$ for the eastern Caribbean Sea and the western tropical North Atlantic region from ${ }^{14} \mathrm{C}$ measurements of an annually banded coral Siderastrea siderea collected alive in early 2008 at îlet Chancel off the eastern coast of Martinique Island in the Lesser Antilles arc $\left(14^{\circ} 70^{\prime} \mathrm{N}\right.$; $60^{\circ} 90^{\prime} \mathrm{W} ; 1.50 \mathrm{~m}$ water depth) (Figure $1 \mathrm{~A}$ ).

\footnotetext{
*Corresponding author. Email: martine.paterne@lsce.ips 1.fr.
} 


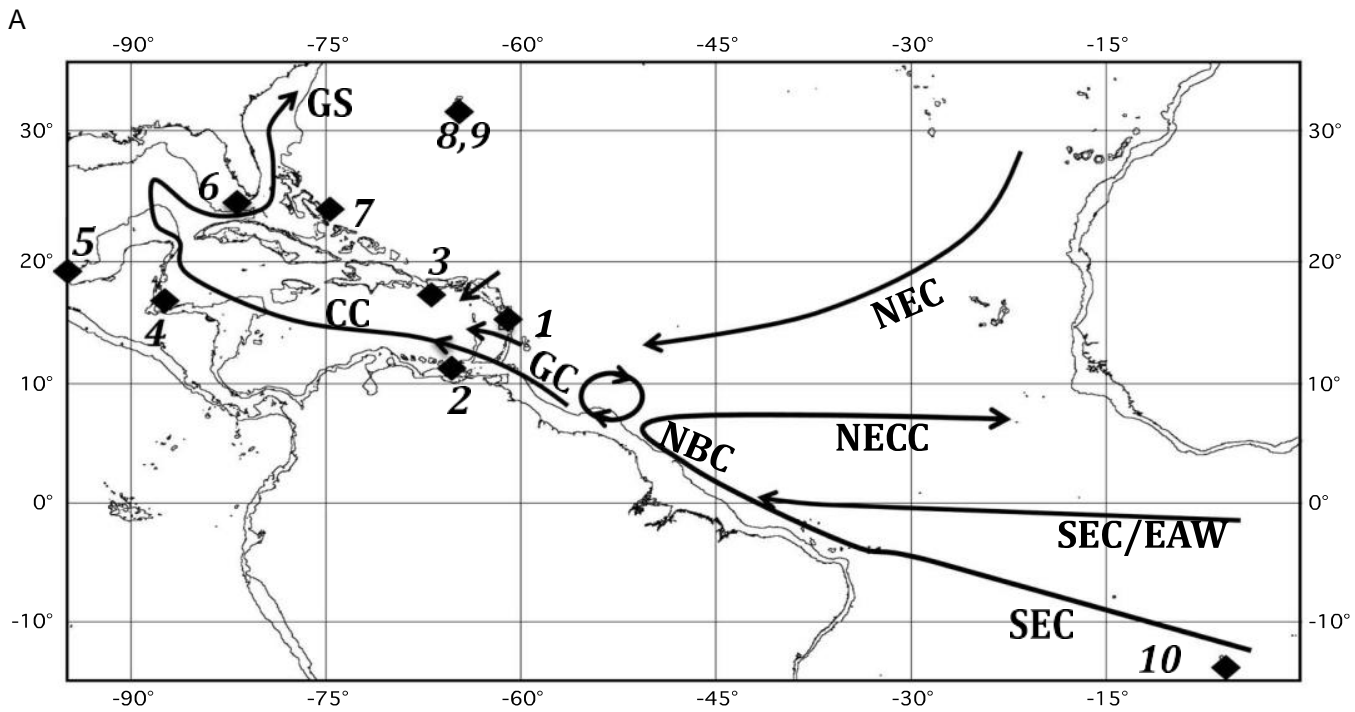

B

C

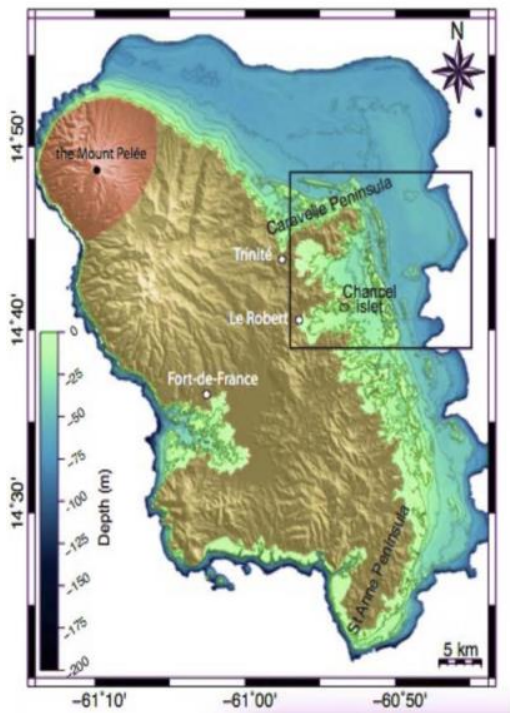

CHANCEL 1

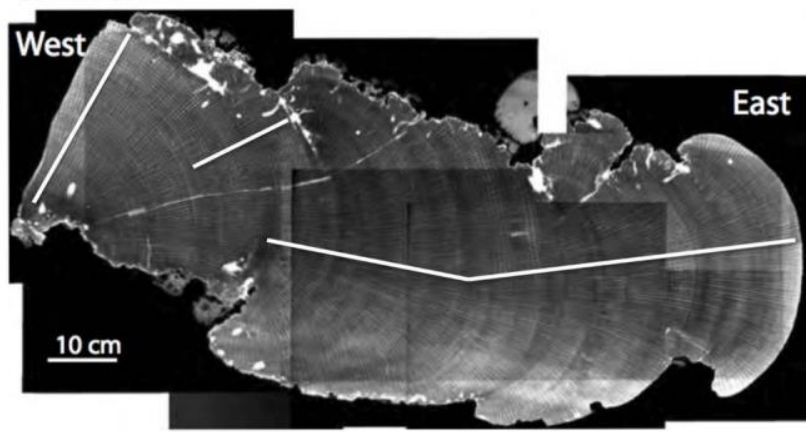

Figure 1 (A) Location of corals, scleroponges, and mollusk shells cited in the text and schematic patterns of the oceanic currents. 1: Martinique; 2: Cariaco basin (Guilderson et al. 2005); 3: Puerto-Rico (Kilbourne et al. 2007); 4: Belize (Druffel 1980); 5: Gulf of Mexico (Wagner et al. 2005); 6: Florida (Druffel and Linick 1978; Druffel 1980, 1982); 7: Bahamas (Fernandez et al. 2012); 8: Bermuda north shore (Druffel 1989; 1997); 9: Bermuda south shore (Goodkin et al. 2012); 10: Santa Helena (Lewis et al. 2008). NEC: North Equatorial current; NECC: North Equatorial undercurrent; NBC: North Brazil current; GC: Guiana current; SEC: South Equatorial current; EAW: East Atlantic current; CC: Caribbean current; GS: Gulf Stream. The 1000-m isobath is represented: (B) location and (C) radiography of coral Chancel 1 . White thick lines represent sampling plates.

Martinique Island is located alongside one of the main passages of the Atlantic inflow (Wilson and Johns 1997; Johns et al. 1999, 2002; Cherubin and Richardson 2007). This island is characterized by sustained volcanic activity with widespread hydrothermal and geothermal fields and diffuse degassing of $\mathrm{CO}_{2}$ from shallow magma chambers. This old mantle-derived $\mathrm{CO}_{2}$ 
dissolves into shallow aquifers and rivers (Rivé et al. 2011) and in coastal seawater from submarine gas vents, mainly located offshore the western coast of Martinique (Gadalia et al. 2015). Residence time of waters in the hydrothermal and geothermal systems may be extremely short ( $<10 \mathrm{yr}$ ), but it is mostly of some hundred years up to ten thousand years (Sanjuan et al. 2005; Rad et al. 2011). In Martinique, river discharges are very small ( $\left.<1 \mathrm{~m}^{3} / \mathrm{s}\right)$ so that sea surface aging by freshwater runoff is unlikely. Only massive destabilization of shallow aquifersas well as active submarine $\mathrm{CO}_{2}$ degassing from geothermal fields, such as during an eruption, may potentially drive local aging of sea surface in coastal areas near coral reefs.

The values of $\mathrm{R}$ are established during two decades marked by a quasi-stable atmospheric ${ }^{14} \mathrm{C}$ content (Stuiver et al. 1998) and by either quiescent or active volcanism between 1835 and 1845 and between 1895 and 1905, respectively. One devastating 2-yr-long eruption of Montagne Pelée volcano, killing 28,000 people, occurred in 1902-1903 on Martinique Island (Lacroix 1904). Values of $\mathrm{R}$ from coral Chancel 1 in Martinique were compared to previous data from corals and scleroponges collected in the subtropical and tropical western North Atlantic (Druffel and Linick 1978; Druffel 1980, 1982, 1997; Druffel and Suess 1983; Guilderson et al. 2005; Kilbourne et al. 2007; Wagner et al. 2009; Goodkin et al. 2012; Fernandez et al. 2015). We analyzed the variability of $\mathrm{R}$ during each decade and a potential effect of volcanic activity on the ${ }^{14} \mathrm{C}$ ages. Oxygen isotope analyses were performed to account for changes of local hydrology, ocean dynamics and volcanism.

\section{MATERIAL AND METHODS}

The full description of coral Chancel 1, which was collected alive in January 2008 at a water depth of $\sim 1.50 \mathrm{~m}$ on the Atlantic coast of Martinique Island, is reported elsewhere (Weil-Accardo et al. 2016) (Figure 1B). The coral slab extends over a 1-m length, and X-radiographs were taken to display the annual density bands (Figure 1C). Chronology is based on the counting of annual bands of growth, Th/U dating and on the correlation of die down surfaces of a series of corals from microatolls sampled south of the Caravelle Peninsula (Weil-Accardo et al. 2016). In addition, U/Th

dating was performed on the growth band years 1849-1851 incoral Chancel 1 with a MC-ICPMSNeptune following previously described procedure (Pons-Branchu et al. 2014) (Table 3). Annual bands were drawn on a tracing overlay of the radiography digitized at the scale of the coral allowing a precise sampling along growth axes using a diamond saw.

X-ray diffraction of random samples was performed using a PANalytical X'Pert Pro diffractometer at the GEOPS Laboratory to infer presence of calcite (Table 1). Oxygen and carbon isotopes were analyzed at the LSCE using an Optima-VG mass spectrometer (isotope ratio mass spectrometer) coupled with a common acid bath and an automated preparation line to produce $\mathrm{CO}_{2}$. The isotope compositions were calibrated against the NBS 18 and 19 standards. Oxygen and carbon isotopic compositions are reported in the classical notation $\delta$ expressed in per mil (\%o) versus PDB (Pee Dee Belemnite). The external precision is 0.02 and $0.04 \%$ o $(1 \sigma)$ for carbon and oxygen respectively. The method for radiocarbon analyses of carbonates was described elsewhere (Tisnerat-Laborde et al. 2001). Chemical pretreatment of coral powder was done using $\mathrm{HNO}_{3}(0.01 \mathrm{~N})$ and rinsed in distilled water. Carbonate hydrolyzes with $\mathrm{H}_{3} \mathrm{PO}_{4}$ in a semi-automatic vacuum line were performed at the Gif-LSCE Radiocarbon Laboratory. Graphite targets were prepared and measured at the French National AMS-ARTEMIS- LMC14 facility (Cottereau et al. 2007). Results are expressed in conventional years BP and the

$\Delta{ }^{14} \mathrm{C} \%$ is the deviations in parts per thousand (\%o) of a sample's ${ }^{14} \mathrm{C} /{ }^{12} \mathrm{C}$ ratio of known age from that of the absolute standard activity in 1950 (Stuiver and Polach 1977). Reservoir age, R, is the difference at the date of coral growth between the measured ${ }^{14} \mathrm{C}$ age and the atmospheric 
${ }^{14} \mathrm{C}$ age using the calibration record single-year IntCal98 (Stuiver et al. 1998), which takes more account of the variability of the atmospheric ${ }^{14} \mathrm{C}$ ages than the calibration record IntCal 13 (Reimer et al. 2013). $\Delta \mathrm{R}$ is the difference between the measured ${ }^{14} \mathrm{C}$ age and the modeled global sea surface age from a global box-diffusion carbon model (Stuiver et al. 1986; Stuiver and Braziunas 1993) using the marine calibration dataset IntCal 04 (Hughen et al. 2004), which is equivalent to the marine IntCal13 over the considered time interval (Reimer et al. 2013).

\section{HYDROLOGIC SETTING AND SEA SURFACE DIC $\Delta^{14} \mathrm{C}$}

The water masses in the western tropical North Atlantic and the eastern Caribbean Sea were previously described in detail (Morrison and Nowlin 1982; Wilson et al. 1994; Stramma and Schott 1999; Stramma et al. 2005; Rhein et al. 2005) and the following description is summarized for the upper water masses $(\sim 500 \mathrm{~m})$ near the Lesser Antilles (Rhein et al. 2005; Kirchner et al. 2009). The tropical surface waters (TSW) at $27^{\circ} \mathrm{C}$ form the mixed layer which are influenced by the freshwater plumes of the Amazon and Orinoco Rivers. These are transportedequatorward by the North Brazil Current (NBC) and the Guiana Current (GC) (Figure 1A) into the western tropical North Atlantic and the Caribbean Sea where they spread extensively (Pailler et al. 1999; Hellweger and Gordon 2002; Ffield 2005, 2006). Below TSW is the under-lying salinity maximum water (SMW) formed by subduction of surface waters at the northern and southern Atlantic tropics/subtropics transitions (Wilson et al. 1994; Stramma et Schott 1999; Stramma et al. 2005; Rhein et al. 2005; Kirchner et al. 2009). The northern surface waters flow westward from the North Atlantic subtropical gyre along the North Equatorial Current (NEC). Surface waters from the South Atlantic gyre and from the east South Atlantic (EAW) flow along the South Equatorial Current (SEC) then the NBC and GC (Wilson et al. 1994; Bourles et al. 1999; Stramma and Schott 1999; Stramma et al. 2005). Anticyclonic rings form at the retroflection of $\mathrm{NBC}$ near $\sim 6^{\circ} \mathrm{N}$ feeding the eastward flowing North Equatorial Counter-

current (NECC). They transport the South Atlantic waters as far as $15-18^{\circ} \mathrm{N}$ along the Atlantic side of the Lesser Antilles islands, where they decay (Hu et al. 2004; Fratantoni and Richards on 2006; Ffield 2005). Below SMW down to $400-500 \mathrm{~m}$ water-depth are found the central waters (CW) (Rhein et al. 2005) which originate from both the South Atlantic Central water (SACW) and the North Atlantic Central water (NACW), zonally separated across the North Atlantic at around $15^{\circ} \mathrm{N}$ (Stramma et al. 2005). SMW from the southern origin are fresher than SMW from the North (Bourles et al. 1999) as well as NACW are saltier and warmer than SACW (Stramma et al. 2005).

The Atlantic inflow into the Caribbean Sea penetrates through the sill passages of the Lesser Antilles, the main ones located to the south of $14^{\circ} \mathrm{N}$ in the Grenada $\left(11^{\circ} \mathrm{N}\right)$ and the St LuciaMartinique $\left(14^{\circ} \mathrm{N}\right)$ passages and to the north in the Antigua and Anegada-Jungfern $\left(17^{\circ} \mathrm{N}\right)$ passages (Morrison and Nowlin 1982; Wilson and Johns 1997; Johns et al. 2002; Cherubin and Richardson 2007). These inflows feed the Caribbean Current flowing westward and northward through the Yucatan strait to feed the Florida Current then the Gulf Stream (Figure 1A).

In the Caribbean region and western tropical North Atlantic, two main hydrologic features will have an impact on the variability of the sea surface $\delta^{18} \mathrm{O}$ and $\Delta^{14} \mathrm{C}$. First, the Martinique Island is exposed all the year round to the E-NE Trade Winds so that sea surface waters will pile up along the roughly northwest/southeast coast of the island, and significant local upwelling cannot form. Second, the well-marked salinity gradient between the fresh buoyant surface waters TSW and the underlying SMW causes a strong pycnocline and a stable barrier layer (BL) in density (Sprintall and Tomczak 1992; Pailler et al. 1999; de Boyer Montégut et al. 2004). It is almost permanent all the year round (de Boyer Montégut et al. 2004, 2007; Mignot et al. 2007) 
and it may be episodically eroded or suppressed by strong winds such as those generated by hurricanes (Grodsky et al. 2012). As the evaporation minus precipitation budget is positive in the region between $10^{\circ} \mathrm{N}$ and $20^{\circ} \mathrm{N}$ (Schmitt et al. 1989; Dessier and Donguy 1994; Hellweger and Gordon 2002), the BL was linked to advective processes and runoff from the Amazon and Orinoco Rivers (Pailler et al. 1999; Mignot et al. 2007; Balaguru et al. 2012). This stable BL separates the density based mixed layer from the thermocline and inhibits wind induced turbulent vertical mixing of the thermocline waters into the surface mixed layer (Pailler et al. 1999; Ffield 2005, 2006; de Boyer Montégut et al. 2007; Mignot et al. 2007).

The sea surface ${ }^{14} \mathrm{C}$ content in the tropical Atlantic and Caribbean Sea was measured in the years $1955-1957$ before the huge ${ }^{14} \mathrm{C}$ input into the atmosphere due to the nuclear tests in the 1960s (Broecker et al. 1960). The values of $\Delta^{14} \mathrm{C}$, corrected from the small bomb ${ }^{14} \mathrm{C}$ input (Broecker et al. 1960), are more depleted in surface waters of SEC due to upwelling than in the NEC ones at $-63 \%$ and $-52 \%$, respectively. In the Caribbean Sea, the sea surface $\Delta^{14} \mathrm{C}$ is around $-56 \%$.

\section{RESULTS}

Results are reported in Tables 1 and 2. Negligible crystallization of calcite $(<1 \%)$ is documented from X-ray diffraction measurements (Table 1). Chancel 1 grew continuously over a time span of $230 \mathrm{yr}$ (Weil-Accardo et al. 2016). The thickness of the annual bands does not vary greatly at an average of $\sim 6 \pm 1 \mathrm{~mm}$ along the growth axis except prior to $\sim 1830 \mathrm{AD}$ when it varies between $\sim 3$ and $4 \mathrm{~mm}$. The uncertainty at $1 \sigma$ on the counting is estimated at $\pm 1 \mathrm{yr}$, except prior

to $1830 \mathrm{AD}$ at $\pm 2 \mathrm{yr}$. Values of $\delta^{234} \mathrm{U}$ are in the accepted range for modern seawater at $\sim 146 \%$ (Delanghe et al. 2002; Robinson et al. 2004; Andersen et al. 2010) (Table 3). The mean Th/U age of $1853 \pm 12(2 \sigma) \mathrm{AD}$ is in close agreement with the counting of the growth band years at 1849 $1851 \mathrm{AD}$ (Weill-Accardo et al. 2016).

Between 1835 and 1845, and 1895 and 1905, the arithmetic means of R at $1 \sigma$ are similarly centered at $385 \pm 30 \mathrm{yr} \mathrm{BP}$ and $382 \pm 20 \mathrm{yr} \mathrm{BP}$, respectively (Figure 2, Table 1). Mean value of $\Delta \mathrm{R}$ in the western tropical Atlantic is close to zero during the two decades. The variability of $\mathrm{R}$ is larger during the oldest decade than during the youngest one, when the Montagne Pelée eruption occurred. Values of R vary from $331 \pm 32$ yr up to $443 \pm 33$ yr during the older decade and from $351 \pm 32$ yr up to $415 \pm 31$ yr during the younger decade.

Values of $\delta^{18} \mathrm{O}$ vary similarly by $0.5-0.6 \%$ around the mean of $-3.9 \%$ o during the two decades. However they exhibit a well-marked increase of $\sim 0.4 \%$ o during the older decade (Figure $3 \mathrm{~A}$ ) while no trend exists during the younger one (Figure $3 \mathrm{~B}$ ). During the older decade, values of $\delta^{18} \mathrm{O}$ and $\Delta^{14} \mathrm{C}$ are significantly correlated at the $95 \%$ confidence level $(\mathrm{r}=0.65)$. At the time of the eruption of Montagne Pelée in 1902-1903, a well-marked $\delta^{18} \mathrm{O}$ high is recorded and it coincides with slightly depleted $\Delta^{14} \mathrm{C}$ values although in the range of uncertainties (Table 1 ).

\section{DISCUSSION}

There is no large regional departure of the sea surface ${ }^{14} \mathrm{C}$ near Martinique from the modeled global mixed layer value (Hughen et al. 2004) $(\Delta \mathrm{R} \approx 0)$ and values of $\mathrm{R}$ are identical at an average of $384 \pm 25 \mathrm{yr}$ between 1935 and 1845 and between 1895 and 1905 . The sea surface variations of ${ }^{14} \mathrm{C}$ off Martinique reproduce mainly the atmospheric ${ }^{14} \mathrm{C}$ changes at steady state in the western tropical North Atlantic/Eastern Caribbean and the ocean-atmosphere ${ }^{14} \mathrm{CO}_{2}$ exchange and ocean dynamics do not vary greatly when comparing the two decades. Nevertheless, the oldest decade records a large range of variations in $\Delta^{14} \mathrm{C}$ and $\delta^{18} \mathrm{O}$ characterized by 
Table $1 \mathrm{Lab}$ codes and values of ${ }^{14} \mathrm{C}$, stable oxygen and carbon isotopes, and calcite content in $\%$ in annual growth bands in coral Chancel $1 .{ }^{14} \mathrm{C}$ ages are expressed in conventional $\mathrm{yr} \mathrm{BP}$. See text for $\mathrm{R}, \Delta \mathrm{R}$, and $\Delta^{14} \mathrm{C}$ calculations.

\begin{tabular}{|c|c|c|c|c|c|c|c|c|c|}
\hline Lab code & $\begin{array}{l}\text { Lab } \\
\text { code }\end{array}$ & $\begin{array}{l}\text { Coral } \\
\text { growth }\end{array}$ & $\begin{array}{l}{ }^{14} \mathrm{C} \\
\text { age } \pm 1 \sigma\end{array}$ & $\Delta^{14} \mathrm{C} \pm 1 \sigma$ & $\mathrm{R} \pm 1 \sigma$ & $\Delta \mathrm{R} \pm 1 \sigma$ & $\delta^{18} \mathrm{O}$ & $\delta^{13} \mathrm{C}$ & Calci \\
\hline SacA & GifA & year (AD) & (yr BP) & (\%o) & (yr) & (yr) & (PDB) & (PDB) & $(\%)$ \\
\hline 37882 & 14387 & 1835 & $555 \pm 30$ & $-53.7 \pm 3.5$ & $443 \pm 33$ & $64 \pm 42$ & -4.02 & -0.20 & - \\
\hline 39852 & 452 & 1836 & $510 \pm 30$ & $-48.5 \pm 3.6$ & $401 \pm 31$ & $19 \pm 40$ & -3.88 & 0.25 & - \\
\hline 37883 & 388 & 1837 & $510 \pm 30$ & $-48.6 \pm 3.6$ & $373 \pm 31$ & $19 \pm 40$ & -3.81 & -0.24 & - \\
\hline 39854 & 14454 & 1838 & $505 \pm 30$ & $-48.1 \pm 3.6$ & $376 \pm 31$ & $15 \pm 39$ & -3.70 & 0.15 & - \\
\hline 37885 & 14390 & 1839 & $500 \pm 20$ & $-47.6 \pm 3.6$ & $383 \pm 33$ & $10 \pm 43$ & -3.69 & 0.34 & - \\
\hline 39855 & 14455 & 1840 & $485 \pm 30$ & $-46.0 \pm 3.6$ & $370 \pm 33$ & $-5 \pm 43$ & -3.73 & 0.51 & - \\
\hline 37886 & 391 & 1841 & $510 \pm 30$ & $-49.1 \pm 3.6$ & $367 \pm 33$ & $20 \pm 43$ & -3.86 & 0.56 & - \\
\hline 39856 & 14456 & 1842 & $535 \pm 30$ & $-52.1 \pm 3.5$ & $420 \pm 32$ & $46 \pm 41$ & -3.68 & 0.65 & - \\
\hline 37887 & 14392 & 1843 & $490 \pm 30$ & $-46.9 \pm 3.6$ & $370 \pm 31$ & $1 \pm 40$ & -3.70 & 0.58 & - \\
\hline 39858 & 14458 & 1844 & $440 \pm 30$ & $-41.1 \pm 3.6$ & $331 \pm 32$ & $-48 \pm 40$ & -3.39 & 0.86 & - \\
\hline 37889 & 14459 & 1845 & $520 \pm 30$ & $-50.7 \pm 3.5$ & $398 \pm 36$ & $32 \pm 48$ & -3.56 & 0.61 & - \\
\hline Mean $(S T D V)$ & & & $505 \pm 29$ & $-48.4 \pm 3.3$ & $385 \pm 30$ & $16 \pm 29$ & & & \\
\hline 37903 & 408 & 1895 & $460 \pm 30$ & $-49.4 \pm 3.6$ & & & -4.07 & -0.80 & - \\
\hline 379 & 14409 & 1896 & $460 \pm 30$ & $-49.5 \pm 3.6$ & 397 & $1 \pm 40$ & -3.88 & -0.10 & - \\
\hline 439 & 15542 & 1897 & $430 \pm 30$ & -46.0 & $=32$ & $-28 \pm 41$ & -3.86 & -0.49 & - \\
\hline 326 & 13058 & 18 & $445 \pm 30$ & $-47.9 \pm 3.6$ & $367 \pm 32$ & $-11 \pm 41$ & -3.87 & -0.71 & 0.57 \\
\hline 32687 & 13059 & 1899 & $450 \pm 30$ & $-48.6 \pm 3.6$ & $364 \pm 32$ & $-5 \pm 41$ & -3.80 & -0.32 & 0.18 \\
\hline 32688 & 13060 & 1900 & $450 \pm 30$ & $-48.7 \pm 3.6$ & $378 \pm 32$ & $-4 \pm 42$ & -3.82 & -0.03 & 0.06 \\
\hline 32689 & 13061 & 1901 & $445 \pm 30$ & $-48.3 \pm 3.6$ & $407 \pm 31$ & $-8 \pm 40$ & -4.06 & -0.57 & 0.07 \\
\hline 32691 & 13063 & 1902 & $485 \pm 30$ & $-53.1 \pm 3.5$ & $415 \pm 31$ & $33 \pm 40$ & -3.60 & 0.14 & 0.06 \\
\hline 32692 & 13064 & 1903 & $470 \pm 30$ & $-51.5 \pm 3.5$ & $390 \pm 32$ & $19 \pm 41$ & -3.75 & 0.09 & 0.39 \\
\hline 32693 & 13065 & 1904 & $440 \pm 30$ & $-48.0 \pm 3.6$ & $361 \pm 32$ & $-10 \pm 41$ & -4.13 & -0.36 & 0.18 \\
\hline 32695 & 13067 & 1905 & $475 \pm 30$ & $-52.3 \pm 3.5$ & $387 \pm 32$ & $26 \pm 41$ & -4.06 & -1.20 & 0.02 \\
\hline Mean $(S T D V)$ & & & $455 \pm 15$ & & & $1 \pm 18$ & & & \\
\hline Total (STDV) & & & $480 \pm 35$ & $-49 \pm 3$ & $384 \pm 25$ & $6 \pm 20$ & & & \\
\hline
\end{tabular}

a moderate increase of $\Delta^{14} \mathrm{C}$ and a well-marked increase of $\delta^{18} \mathrm{O}$ of $\sim 0.4 \%$, which is not observed during the youngest decade (Figure 3 ).

The variations of $\delta^{18} \mathrm{O}$ reflect the changes of the sea surface temperatures (SST) and sea surface salinities (SSS), due to changes in the evaporation-precipitation budget and runoff. In addition, in the eastern Caribbean Sea, SSS also depend on the oceanic current patterns (Hellwegger and Gordon 2002) and they may be punctually related to changes in volcanic activity. Although in this region rainfalls play a minor role in changing the sea surface salinities (Schmitt et al. 1989; Dessier and Donguy 1994; Hellweger and Gordon 2002), we analyzed their local influence by comparing the records of $\delta^{18} \mathrm{O}$ and precipitation on Martinique Island. The fluctuations of $\delta^{18} \mathrm{O}$ in coral Chancel 1 are analyzed using available records of SST (ersst.v3 at ncdc.noaa.gov/dat aaccess/marineocean-data; Xue et al. 2000; Smith et al. 2006), the precipitation records (www. climexp.knmi.nl; van Oldenborgh and Burgers 2005) as well as the values of $\delta^{18} \mathrm{O}$ of seawater near volcanic gas vents and in groundwaters (McCarthy et al. 2005; Sanjuan et al. 2005; Jones et al. 2011; Hemmings et al. 2015; Sanjuan and Brach 2015). We first compared the sea surface ${ }^{14} \mathrm{C}$ values in coral Chancel 1 with previous data from the tropical and subtropical North 
Table 2 Mean values of $\Delta^{14} \mathrm{C}$, R, and number (nr) of values between 1835 and 1845 and between 1895 and 1905. * refers to values in IntCal98 (Stuiver et al. 1998) and numbers in parentheses to coral sites cited in the text. Same legends as in Figure 1.

\begin{tabular}{|c|c|c|c|c|c|c|}
\hline & \multicolumn{3}{|l|}{$1835-1845$} & \multicolumn{3}{|l|}{$1895-1905$} \\
\hline & $\begin{array}{l}\Delta^{14} \mathrm{C} \pm 1 \sigma \\
(\%)\end{array}$ & $\begin{array}{l}\mathrm{R} \pm 1 \sigma \\
(\mathrm{yr})\end{array}$ & $\mathrm{Nr}$ & $\begin{array}{l}\Delta^{14} \mathrm{C} \pm 1 \sigma \\
(\%)\end{array}$ & $\begin{array}{l}\mathrm{R} \pm 1 \sigma \\
(\mathrm{yr})\end{array}$ & $\mathrm{Nr}$ \\
\hline Atmosphere* & $-2 \pm 1$ & $121 \pm 11$ & 11 & $-3 \pm 2$ & $73 \pm 14$ & 11 \\
\hline Bermuda-North (9) & & & & $-45.4 \pm 2.4$ & $348 \pm 32$ & 8 \\
\hline Bermuda-South (8) & $-39 \pm 2$ & $298 \pm 21$ & 6 & $-41.0 \pm 1.9$ & $311 \pm 32$ & 6 \\
\hline Bahamas (7) & & & & $-54.2 \pm 2.8$ & $408 \pm 20$ & 2 \\
\hline Florida (6) & $-55.5 \pm 3$ & $448 \pm 30$ & 2 & $-49.0 \pm 5.0$ & $381 \pm 40$ & 6 \\
\hline Gulf Mexico (5) & & & & $-43.9 \pm 3.4$ & $344 \pm 32$ & 1 \\
\hline Belize (4) & & & & $-48.5 \pm 3.1$ & $371 \pm 21$ & 4 \\
\hline Puerto Rico (3) & $-51.9 \pm 4.2$ & $418 \pm 45$ & 3 & $-49.7 \pm 1.0$ & $381 \pm 19$ & 3 \\
\hline Martinique (1) & $-48.4 \pm 3.3$ & $385 \pm 30$ & 11 & $-49.4 \pm 2.1$ & $382 \pm 20$ & 11 \\
\hline Islas Tortugas (2) & & & & $-42.2 \pm 4.6$ & $306 \pm 38$ & 1 \\
\hline
\end{tabular}

Table 3 Results of uranium-thorium dating of two aliquots of the growth year bands 18491851. The $\mathrm{Th} / \mathrm{U}$ ages are expressed as years before 1950 (yr BP) or in calendar years (AD). "Age cor" are corrected for detrital thorium using a mean marine ${ }^{230} \mathrm{Th} /{ }^{232} \mathrm{Th}$ activity ratio of $10 \pm 4$ (Frank et al. 2004), close to the estimated correction of the non-radiogenic ${ }^{230} \mathrm{Th}$ in one Haitian coral (Weil-Accardo et al. 2016). Errors are propagated and are given at the $2 \sigma$ confidence level.

\begin{tabular}{|c|c|c|c|c|c|c|c|c|}
\hline $\begin{array}{l}\text { Lab } \\
\text { sample }\end{array}$ & $\begin{array}{l}{ }^{238} \mathrm{U} \\
(\mathrm{ppb}) \\
\end{array}$ & $\begin{array}{l}{ }^{232} \mathrm{Th} \\
(\mathrm{ppb})\end{array}$ & ${ }^{230} \mathrm{Th} /{ }^{238} \mathrm{U}$ & ${ }^{230} \mathrm{Th} /{ }^{232} \mathrm{Th}$ & $\begin{array}{l}\delta{ }^{234} \mathrm{U}_{0} \\
(\%)\end{array}$ & $\begin{array}{l}\text { Age } \\
(\mathrm{yr} B P)\end{array}$ & $\begin{array}{l}\text { Age cor. } \\
\text { (yr BP) }\end{array}$ & $\begin{array}{l}\text { Age cor. } \\
\text { (AD) }\end{array}$ \\
\hline 6261 & $3073 \pm 5$ & $0.3260 \pm 0$ & $0.00218 \pm 0.0$ & $63.74 \pm 1.10$ & $145.9 \pm 0.8$ & $144 \pm 2$ & $111 \pm 15$ & $1839 \pm 15$ \\
\hline 6392 & $2916 \pm 17$ & $0.4054 \pm 0.0018$ & $0.00198 \pm 0.00002$ & $45.36 \pm 0.47$ & $146.7 \pm 1.2$ & $124 \pm 2$ & $82.5 \pm 18.5$ & $1867.5 \pm 18.5$ \\
\hline
\end{tabular}

Atlantic (Druffel and Linick 1978; Druffel 1980; Druffel and Suess 1983; Druffel 1982 1997; Guilderson et al. 2005; Kilbourne et al. 2007; Wagner et al. 2009; Goodkin et al. 2012; Fernandez et al. 2015). We then analyzed the variability of $\delta^{18} \mathrm{O}$ and $\Delta^{14} \mathrm{C}$, linked to local hydrology, ocean dynamics, and volcanism.

\section{COMPARISON OF R AND $\triangle^{14} \mathrm{C}$ IN CHANCEL 1 AND IN CORALS AND SCLEROPONGES OF THE TROPICAL AND SUBTROPICAL WESTERN NORTH ATLANTIC}

The mean values of $\mathrm{R}$ and $\Delta^{14} \mathrm{C}$ near Martinique compare well with previous ones (Table 2): in Puerto Rico (Kilbourne et al. 2007), Belize (Druffel 1980; Druffel and Suess 1983), the Gulf of Mexico (Wagner et al. 2009), the Florida Strait within the Gulf Stream (Druffel and Linick 1978; Druffel 1980, 1982, 1997; Druffel and Suess 1983), and the Bahamas (Fernandez et al. 2015). In one instance, slightly higher $\Delta^{14} \mathrm{C}$ than observed in the whole Caribbean Sea is observed from one coral near Islas Tortugas in the Cariaco basin, but it is based only on a one-year average (Guilderson et al. 2005). No gradient in the mean $\Delta^{14} \mathrm{C}$ is observed between the Atlantic inflow east off Martinique Island and the Caribbean Sea and Gulf Stream.

Values off Martinique are older than the subtropical North Atlantic ones considering coral records from either the northern or the southern shorelines off Bermuda (Druffel 1989, 1997; Goodkin et al. 2012). Compared to values of $\mathrm{R}$ and $\Delta^{14} \mathrm{C}$ from the southern coral, which 
A

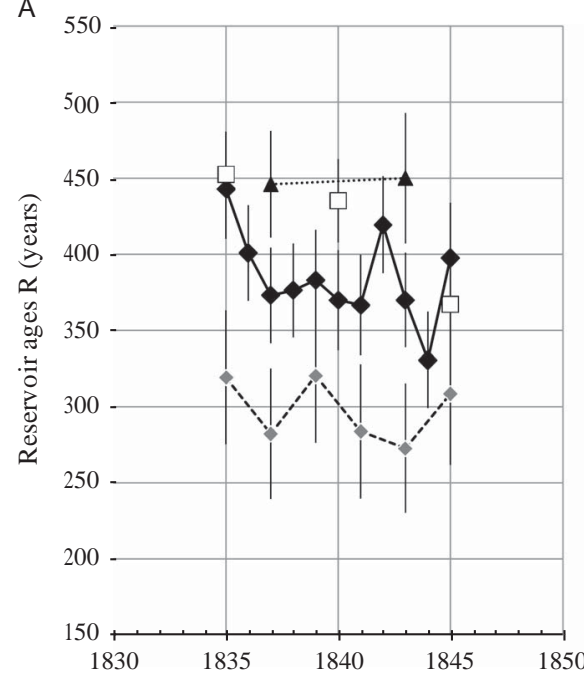

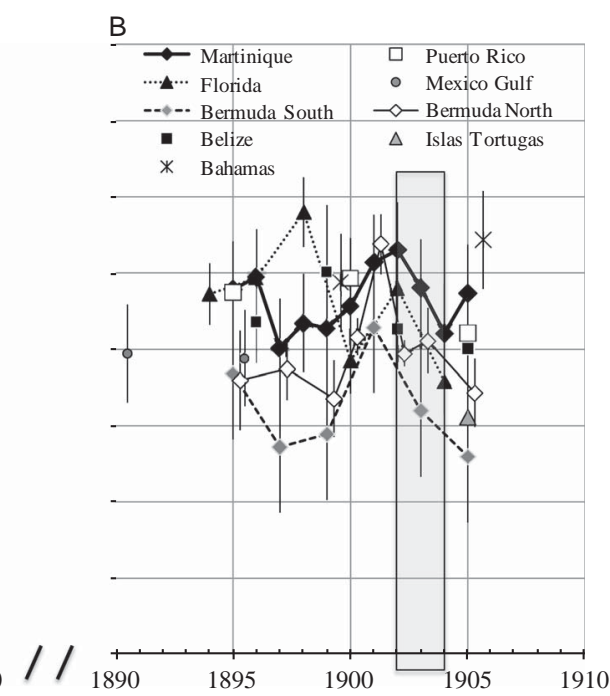

Figure 2 Values of sea surface reservoir ages $\mathrm{R}(\mathrm{yr})$ off Martinique and at the sites located in Figure $1 \mathrm{~A}$ as a function of calendar years (AD) between years (A) 1835-1845 and (B) 1895-1905. The gray box in (B) marks the 2-yr-long eruption of Montagne Pelée. The legend in (B) also pertains to (A).

characterizes open ocean conditions in the subtropical gyre (Goodkin et al. 2012), they differ by 70-90 yr and 8-9\%o in Chancel 1, respectively, over the two decades (Figure 2). The difference in $\Delta^{14} \mathrm{C}$ compares well with the $\sim 11 \%$ offset between the SEC and NEC DIC $\Delta^{14} \mathrm{C}$, the southern waters having the most ${ }^{14} \mathrm{C}$-depleted values (Broecker et al. 1960). The aging of the tropical sea surface off Martinique Island reflects the imprint of the South Atlantic Waters transported by the SEC/NBC/GC along the Lesser Antilles arc and into the Caribbean Sea.

\section{Fluctuations of $\delta^{18} \mathrm{O}$ and $\Delta^{14} \mathrm{C}$ in Coral Chancel 1}

\section{Changes in $\delta^{18} \mathrm{O}$ between 1835 and 1845}

The $\delta^{18} \mathrm{O}$ and SST in carbonates are commonly negatively correlated, the more depleted the $\delta^{18} \mathrm{O}$, the warmer the SST, and vice versa (Weber and Woodhead 1972). The correlation between available SST between 1895 and 1905 (Xue et al. 2000; Smith et al. 2006) and $\delta^{18} \mathrm{O}$ is positive (Figures 4A, 4B). This implies that the variations of $\delta^{18} \mathrm{O}$ are dominated by sea surface salinity changes (SSS), the low salinities corresponding to depleted $\delta^{18} \mathrm{O}$ values, and vice versa. The mean annual precipitation on Martinique Island are very similar between 1835 and 1945 (2270 mm/yr) and between 1895 and 1905 (2200 mm/yr) (van Oldenborgh and Burgers 2005) (Figures 4C, 4D). The changes of the salinity-dependent $\delta^{18} \mathrm{O}$ are not correlated to the variations in the mean annual precipitation on Martinique Island in agreement with previous findings (Dessier and Donguy 1994; Hellweger and Gordon 2002; Folz et al. 2004). Furthermore, the annual and interannual variations of evaporation are weak in the Caribbean region (Yoo and Carton 1990; Dessier and Donguy 1994; Hellweger and Gordon 2002; Folz et al. 2004) so that the increase of $\delta^{18} \mathrm{O}$ between 1835 and 1845 cannot be due to evaporation processes. As the density BL prevents vertical mixing in this region (Pailler et al. 1999; Sprintall and Tomczak 1992; de Boyer Montégut et al. 2004), the changes of the salinity-dependent $\delta^{18} \mathrm{O}$ near Martinique are therefore related to advective processes, as previously stated (Dessier and Donguy 1994; Hellweger and Gordon 2002). In the southeast Caribbean Sea, the SSS changes are highly 

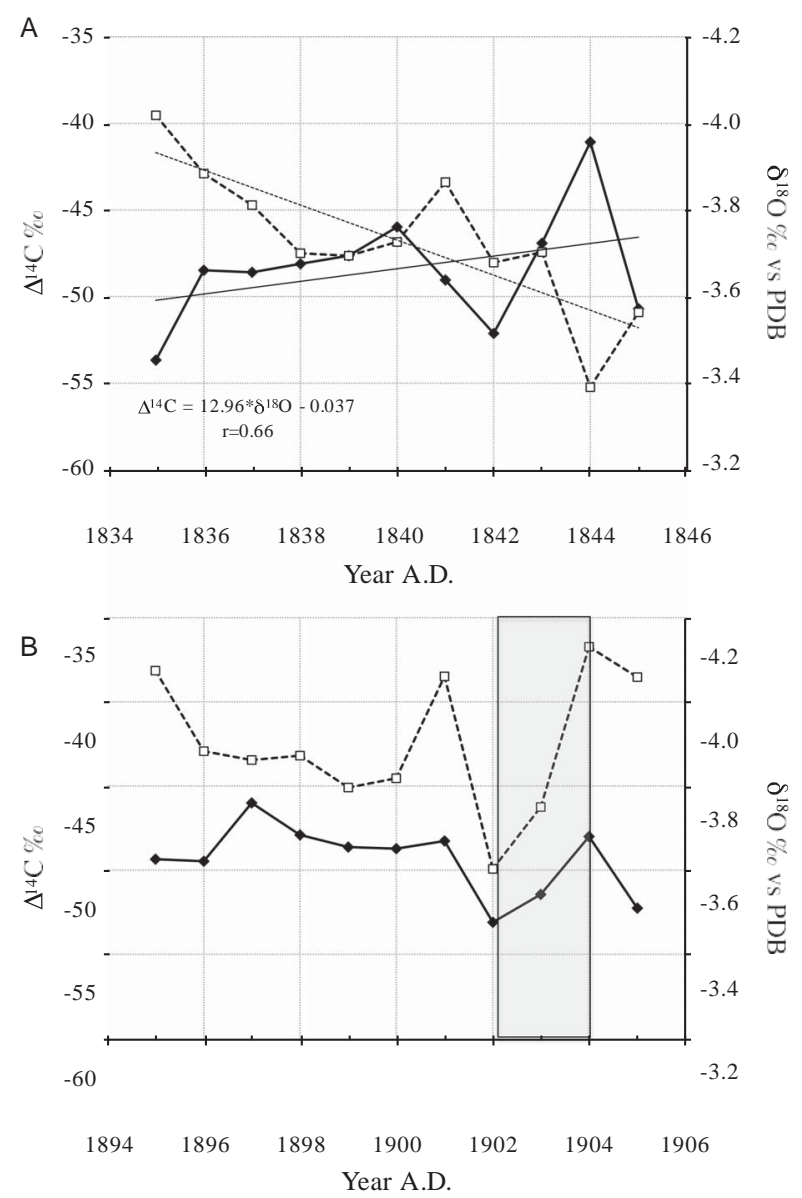

Figure 3 Variations of $\Delta^{14} \mathrm{C}$ (\%) (left axis, black diamonds) and $\delta^{18} \mathrm{O}(\% \circ \mathrm{PDB})$ (right axis, open squares) between (A) 1835 and 1845 and (B) 1895 and 1905. The gray box in (B) marks the 2-yrlong eruption of Montagne Pelée.

correlated to the Amazon River freshwater discharges (Hellwegger and Gordon 2002), the influence of which was felt far from the river mouth by depleted $\delta^{18} \mathrm{O}$ (Karr and Showers 2002) and low SSS (Ffield 2005). Changes of $\delta^{18} \mathrm{O}$ between 1835 and 1845 are thus attributed to variations in either the magnitude of the Amazon and Orinoco runoff or in the current strength of the SEC/NBC/GC, which transport the South Atlantic Waters (SAW) into the western tropical North Atlantic and Caribbean Sea, or both.

Changes in Oceanic Water Masses Advection off Martinique Island between 1835 and 1845 The South Atlantic Waters (SAW), transported northward into the Caribbean Sea, are characterized by low SSS, related to the Amazon River discharges (Hellwegger and Gordon 2002) and by low $\Delta^{14} \mathrm{C}$ (Broecker et al. 1960). Thus the increase of both $\delta^{18} \mathrm{O}$ and $\Delta^{14} \mathrm{C}$ off Martinique between 1835 and 1945 requires a decrease in the strength of the SEC/NBC/GC and thus in the freshwater advection. Changes in SAW advection into the eastern Caribbean across the sills were previously pointed out from repeated hydrographic surveys (Wilson and Johns 1997; Johns et al. 2002; Rhein et al. 2005). Similarly, variations in the northward extent of equatorial water masses was also evidenced in the northern Caribbean Sea at Puerto Rico from a post1963 coral record of $\Delta^{14} \mathrm{C}$ (Kilbourne et al. 2007). 
The fraction of SAW in TSW is not well assessed and it is estimated in SMW at 20-30\% along the Lesser Antilles arc up to $\sim 15^{\circ} \mathrm{N}$ (Rhein et al. 2005; Kirchner et al. 2009). Using a $25 \%$ SAW fraction in TSW, similarly as in SMW, and NEC $\Delta^{14} \mathrm{C}$ at $\sim-39 \%$ o in $\sim 1835$ (Goodkin et al. 2012) (Table 2), one may calculate a $\Delta^{14} \mathrm{C}$ value of the SEC at $-85 \%$ o when $\Delta^{14} \mathrm{C}$ is $\sim-50 \%$ o in 1835 off Martinique. This calculated value is identical to the one determined at $\sim-85 \%$ o in $\mathrm{AD}$ 1815-1835 at Santa Helena located within the southern branch of the SEC (Lewis et al. 2008). To augment the $\Delta^{14} \mathrm{C}$ near Martinique by $~ 5 \%$ such as from 1835 to 1845 , the SAW fraction might be reduced from $25 \%$ to $15 \%$.

\section{Changes of $\delta^{18} \mathrm{O}$ during the 1902- 1903 Eruption of Montagne Pelée}

Warm and salty surface waters prevailed at the time of the eruption (Figure 4A). The values of $\delta^{18} \mathrm{O}$ from hydrothermal and geothermal fluids are mainly depleted with respect to those of seawater in the Lesser Antilles volcanic arc. Hydrothermal fluids from aquifers and groundwaters have very depleted $\delta^{18} \mathrm{O}$ varying between about $0 \%$ and $-4 \%$ versus SMOW (Jones et al. 2011; Hemmings et al. 2015; Sanjuan and Brach 2015), compared to the seawater value ( 1\%o versus SMOW; McCarthy et al. 2005; Sanjuan and Brach 2015). Similarly, $\delta^{18} \mathrm{O}$ from $\mathrm{CO}_{2}$ degassing in submarine gas vents vary between values of seawater and those of the $\delta^{18} \mathrm{O}$ depleted meteoritic waters ( - 2\%o/SMOW) and the largest vents of highest flow rate have $\delta^{18} \mathrm{O}$ values closer to the meteoritic ones (McCarthy et al. 2005). However few positive values of

$$
\text { A }
$$

A

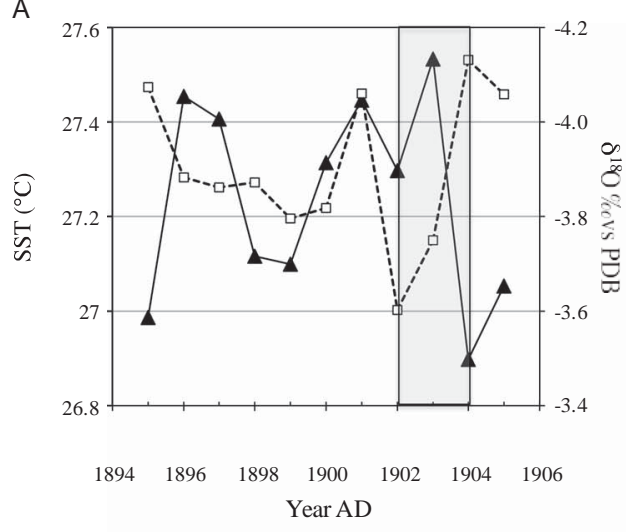

C

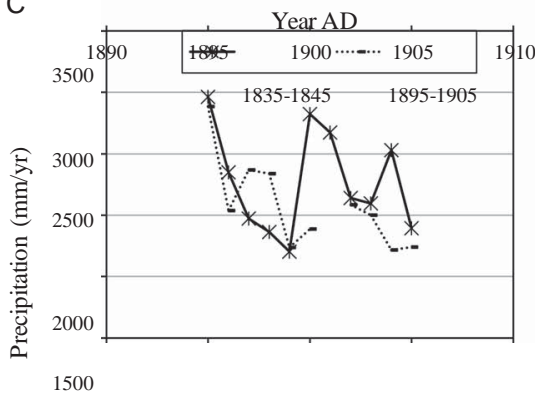

$\begin{array}{lllll}1000 & & & & \\ 1830 & 1835 & 1840 & 1845 & 1850\end{array}$
B

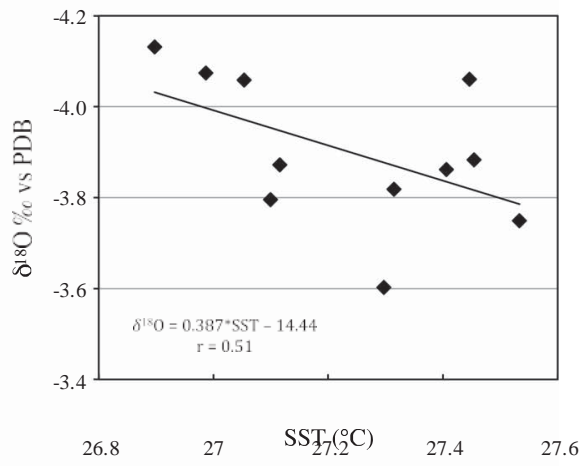

D

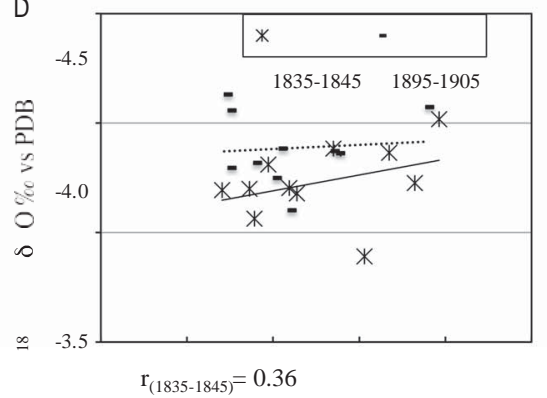

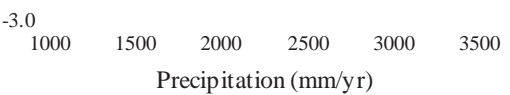

Figure 4 (A) Variations of the mean annual SST $\left({ }^{\circ} \mathrm{C}\right.$ ) (left axis, black triangles) at $\sim 16^{\circ} \mathrm{N} ; 61^{\circ} \mathrm{W}$ (Xueet al. 2000; Smith et al. 2006) and $\delta^{18} \mathrm{O}$ (\%o versus PDB) (right axis, open squares) and (B) variations of $\delta^{18} \mathrm{O}$ as a function of the mean annual SST $\left({ }^{\circ} \mathrm{C}\right)$ between 1895 and 1905 ; (C) variations of the mean annual precipitation (in mm/year) on Martinique Island (van Oldenborgh and Burgers 2005) and (D) variations of $\delta^{18} \mathrm{O}$ as a function of the mean annual precipitation between 1835 and 1845 and between 1895 and 1905. 
$\delta^{18} \mathrm{O}$, higher than the seawater one, were measured at $+2.5 \%$ in geothermal fluids from hot water ponds on the southern seashore on Montserrat Island (Hemmings et al. 2015) and at $\sim+2 \%$ on the western seashore of Martinique (Sanjuan et al. 2005). Thus, the observed increase of $\delta^{18} \mathrm{O}$ in Chancel 1 could be linked to enhanced seaward discharge of geothermal fluids when the eruption occurred, although volcanic fluids are statistically characterized by $\delta^{18} \mathrm{O}$-depleted values and hot water ponds are mainly located on the western coast of Martinique (Sanjuan et al. 2005; Gadalia et al. 2015). This feature, if it exists, would account for a slight $\Delta^{14} \mathrm{C}$ decrease of $5 \%$, that is in the range of uncertainties (Table 1).

\section{CONCLUSION}

Values of $\mathrm{R}$ and $\Delta^{14} \mathrm{C}$ for the eastern Caribbean Sea and the western tropical North Atlantic are quantified from one annually banded coral Chancel 1 collected on the eastern coast of Martinique Island.

The mean values of $\mathrm{R}$ and $\Delta^{14} \mathrm{C}$ are similar between 1835 and 1845 and between 1895 and 1905 with an average of $385 \pm 25 \mathrm{yr}$ and $-49 \pm 3 \%$ o respectively for the two decades. No gradient in the mean values of $\mathrm{R}$ and $\Delta^{14} \mathrm{C}$ is observed along the Caribbean Current from the eastern Caribbean Sea to the Florida Straits. A positive gradient of about $~ 70-90$ yr and 8-9\%o, respectively, is observed between the tropical and subtropical regions of the North Atlantic in agreement with the advection of the old South Atlantic Waters by the SEC/NBC/GC into the Caribbean Sea and the northwestern tropical Atlantic.

Sea surface aging due to enhanced volcanic activity such as during the 2-yr-long eruption of Montagne Pelée cannot be completely excluded. It could amount to some $\sim 40 \mathrm{yr}\left(\Delta^{14} \mathrm{C} \sim 5 \%\right.$ o), which is in the range of dating uncertainties.

Between 1835 and 1845, a reduced northward advection of the South Atlantic Waters, characterized by low SSS and low $\Delta^{14} \mathrm{C}$, towards the Martinique Island is inferred from the well-correlated increase of both $\delta^{18} \mathrm{O}$ and $\Delta^{14} \mathrm{C}$. Using modern estimates of the SAW fraction around the Lesser Antilles (Kirchner et al. 2009) and values of $\Delta^{14} \mathrm{C}$ in the South Atlantic (Lewis et al. 2008) and subtropical North Atlantic (Goodkin et al., 2012), we calculated that the SAW fraction off Martinique Island was reduced from $25 \%$ to $15 \%$ from 1835 to 1845 . Thus, although the sea surface $\Delta^{14} \mathrm{C}$ compare well between the two decadal records in the western tropical North Atlantic, their variability indicates changes in ocean dynamics.

\section{ACKNOWLEDGMENTS}

This work received the financial support of the CEA-CNRS-UVSQ, the CNRS/INSU programs: OA/Leffe-ARRA, ST/PERSEIS; the ACI-FNS Risques Naturels et Changement climatique and the ANR SUBSISMANTI. Thanks are due to E. Kaltnecker, C. Noury, L. Foliot, and F. Manssouri for technical support and the LMC14 team for graphite targets preparation and $\mathrm{AMS}-{ }^{14} \mathrm{C}$ measurements. M. Fontugne and $\mathrm{P}$. Laceby are thanked for their helpful discussions and suggestions.

\section{REFERENCES}

Andersen MB, Stirling CH, Zimmermann B, Halliday AN. 2010. Precise determination of the open ocean ${ }^{234} \mathrm{U} /{ }^{238} \mathrm{U}$ composition. Geochemistry, Geophysics, Geosystems 10.1029/2010GC003318.
Balaguru K, Chang P, Saravanan P, Jang CJ. 2012. The barrier layer of the Atlantic warmpool: formation mechanism and influence on the mean climate. Tellus A: Dynamic Meteorology and Oceanography 64:1:18162. 
Bourlès B, Gouriou Y, Chuchla R. 1999. On the circulation in the upper layer of the western equatorial Atlantic. Journal of Geophysical Research 104:21151-70.

Broecker WS, Gerard R, Ewing M, Heezen BC. 1960. Natural radiocarbon in the Atlantic. Journal of Geophysical Research 65:2903-31.

Chérubin LM, Richardson PL. 2007. Caribbean current variability and the influence of the Amazon and Orinoco freshwater plumes. DeepSea Research I 54:1451-73.

Cottereau E, Arnold M, Moreau C, Baqué D, Bavay D, Caffy I, Comby C, Dumoulin JP, Hain S, Perron M, Salomon J, Setti V. 2007. Artemis, the new ${ }^{14} \mathrm{C}$ AMS at LMC14 in Saclay, France. Radiocarbon 49(2):291-9.

de Boyer Montégut C, Madec G, Fischer AS, Lazar A, Iudicone D. 2004. Mixed layer depth over the global ocean: an examination of profile data and a profilebased climatology. Journal of Geophysical Research 109:C12003 DOI: 10.1029/2004JC002378.

de Boyer Montégut C, Mignot J, Lazar A, Cravatte S. 2007. Control of salinity on the mixed layer depth in the world ocean: 1. General description. Journal of Geophysical Research 112:C06011 DOI: 10.1029/2006JC003953.

Delanghe D, Bard E, Hamelin B. 2002. New TIMS constraints on the uranium-238 and uranium-234 in seawaters from the main ocean basins and the Mediterranean Sea. Marine Chemistry 80(1):79-93.

Dessier A, Donguy JR. 1994. The sea surface salinity in the tropical Atlantic between $10^{\circ} \mathrm{S}$ and $30^{\circ} \mathrm{N}-$ seasonal and interannual variations (1977-1989). Deep-Sea Research I 41:81-100.

Druffel ERM. 1980. Radiocarbon in annual coral rings of Florida and Belize. Radiocarbon 22(2): 363-71.

Druffel ERM. 1982. Banded corals: changes in oceanic carbon-14 during the Little Ice Age. Science 218: 13-9.

Druffel ERM. 1997. Pulses of rapid ventilation in the North Atlantic surface ocean during the past century. Science 275:1454-7.

Druffel EM, Linick TW. 1978. Radiocarbon in annual coral rings from Florida. Geophysical Research Letters 5:913-6.

Druffel ERM, Suess HE. 1983. On the radiocarbon record in banded corals: exchange parameters and net transport of ${ }^{14} \mathrm{CO}_{2}$ between atmosphere and surface ocean. Journal of Geophysical Research 88(C2):1271-80.

Fernandez A, Lapen TJ, Andreasen R, Swart PK, White CD, Rosenheim BE. 2015. Ventilation time scales of the North Atlantic subtropical cell revealed by coral radiocarbon from the Cape Verde Islands. Paleoceanography 30:938-48. DOI: $10.1002 / 2015$ PA 002790 .

Ffield A. 2005. North Brazil current rings viewed by TRMM Microwave Imager SST and the influence of the Amazon Plume. Deep-Sea Research I 52:137-60.
Ffield A. 2006. Amazon and Orinoco River Plumes and NBC Rings: Bystanders or Participants in

Hurricane Events? Journal of Climate 20:316-33. DOI: $10.1175 /$ JCLI3985.1.

Frank N, Paterne M, Ayliffe L, van Weering T, Henriet JP, Blamart D. 2004. Eastern North Atlantic deep-sea corals: tracing upper intermediate water $\Delta^{14} \mathrm{C}$ during the Holocene. Earth and Planetary Science Letters 219(3):297-309.

Fratantoni DM, Richardson PL. 2006. The evolution and demise of North Brazil current rings. Journal of Physical Oceanography 36(7):1241-64.

Gadalia A, Baltassat J-M, Bouchot V, Caritg-Monnot S, Gal F, Girard JF, Gutierrez A, Jacob T, Martelet G, Coppo N, Rad S, Tailame A-L, Traineau H, Vittecoq B, Wawrzyniak P. 2015. The Petite Anse-Diamant geothermal system (Martinique Island, Lesser Antilles): results of the 2012-2013 Exploration. Proceedings of the World Geothermal Congress. Melbourne, Australia, 19-25 April 2015.

Goodkin N, Druffel ERM, Hughen KA, Doney SC. 2012. Two centuries of limited variability in subtropical North Atlantic thermocline ventilation. Nature Communications. 3803. DOI: 10.1038/ ncomms 1811 .

Grodsky SA, Reul N, Lagerloef G, Reverdin G, Carton JA, Chapron B, Quilfen Y, Kudryavtsev VN, Kao HY. 2012. Haline hurricane wake in the Amazon/Orinoco plume: AQUARIUS/SACD and SMOS observations. Geophysical Research Letters 39:L20603. DOI: 10.1029/2012GL053335.

Guilderson TP, Cole JE, Southon JR. 2005. Pre-bo mb $\Delta^{14} \mathrm{C}$ variability and the Suess effect in Cariaco basin surface waaters as recorded in hermatypic corals. Radiocarbon 47(1):57-65.

Hellweger FL, Gordon AL. 2002. Tracing Amazon River water into the Caribbean Sea. Journal of Marine Research 60:537-49.

Hemmings B, Gooddy D, Whitaker F, Darling WG, Jasim A, Gottsmann J. 2015. Groundwater recharge and flow on Montserrat, West Indies: insights from groundwater dating. Journal of Hydrology: Regional Studies 4:611-22.

Hu C, Montgomery ET, Schmitt RW, Muller-Karger FE. 2004. The dispersal of the Amazon and Orinoco River water in the tropical Atlantic and Caribbean Sea: observation from space and SPALACE floats. Deep-Sea Research II 51: 1151-71.

Hughen KA, Baillie MGL, Bard E, Bayliss A, Beck JW, Bertrand C, Blackwell PG, Buck CE, Burr G, Cutler KB, Damon PE, Edwards RL, Fairbanks RG, Friedrich M, Guilderson TP, Kromer B, McCormac FG, Manning S, Bronk Ramsey C, Reimer PJ, Reimer RW, Remmele S, Southon JR, Stuiver M, Talamo S, Taylor FW, van der Plicht J, Weyhenmeyer CE. 2004. Marine04 marine radiocarbon age calibration, 0-26 cal kyr BP. Radiocarbon 46(3):1059-86. 
Johns E, Wilson WD, Molinari R. 1999. Direct observations of velocity and transport in the passages between the Intra-Americas Sea and the Atlantic Ocean, 1984-1996. Journal of Geophysical Research 104 25:805-20.

Johns WE, Townsend TL, Fratantoni DM, Wilson WD. 2002. On the Atlantic inflow into the

Caribbean Sea. Deep-Sea Research I 49:211-43. Jones MT, Hembury DJ, Palmer MR, Tonge B, Darling WG, Loughlin SC. 2011. The weathering and element fluxes from active volcanoes to the oceans: a Montserrat case study. Bulletin of Volcanology 73:207-22.

Karr JD, Showers WJ. 2002. Stable oxygen and hydrogen isotopic tracers in Amazon shelf waters during Amasseds. Oceanologica Acta 25:71-8.

Kilbourne KH, Quinn TM, Guilderson TP, Webb RS, Taylor FW. 2007. Decadal- to interannual-scale source water variations in the Caribbean Sea recorded by Puerto Rican coral radiocarbon. Climate Dynamics 29:51-62. DOI: 10.1007/ s00382-007-0224-2.

Kirchner K, Rhein M, Hüttl-Kabus S, Böning CW . 2009. On the spreading of South Atlantic Water into the Northern Hemisphere. Journal of Geophysical Research 11:C05019 DOI: 10.1029/ 2008JC005165.

Lacroix. 1904. La Montagne Pelée et ses Eruptions. Paris: Masson et Cie. 662 p.

Lewis CA, Reimer PJ, Reimer RW. 2008. Marine Reservoir corrections: St Helena, South Atlantic Ocean. Radiocarbon 50(2):275-80.

McCarthy KT, Pichler T, Price RE. 2005. Geochemistry of Champagne Hot Springs shallow hydrothermal vent field and associated sediments, Dominica, Lesser Antilles. Chemical Geology 224:55-68.

Mignot J, de Boyer Montégut C, Lazar A, Cravatte S. 2007. Control of salinity on the mixed layer depth in the world ocean: 2. Tropical areas. Journal of Geophysical Research 112, C10010, DOI: 10.1029/2006JC003954.

Morrison JM, Nowlin WD Jr. 1982. General Distribution of Water Masses Within the Eastern Caribbean Sea During the winter of 1972 and fall of 1973. Journal of Geophysical Research Ocean 87:4207-29.

Pailler K, Bourlès B, Gouriou Y. 1999. The Barrier Layer in the Western Tropical Atlantic Ocean. Geophysical Research Letters 26:2069-72.

Pons-Branchu E, Douville E, Roy-Barman M, Dumont E, Branchu P, Thil F, Borst W. 2014. A geochemical perspective on Parisian urban history based on U-Th dating, laminae counting and yttrium and REE concentrations of recent carbonates in underground aqueducts. Quaternary Geochronology 24:44-53.

Rad S, Rivé K, Allègre CJ. 2011. Weathering regime associated with subsurface circulation on volcanic islands. Aquatic Geochemistry. 221-41. DOI 10.1007/s 10498-01 1-9122-7.
Reimer PJ, Bard E, Bayliss A, Beck JW, Blackwell PG, Bronk Ramsey C, Buck CE, Edwards RL, Friedrich M, Grootes PM, Guilders on TP, Haflidason H, Hajdas I, Hatté C, Heaton TJ, Hogg AG, Hughen KA, Kaiser KF, Kromer B, Man- ning SW, Reimer RW, Richards DA, Scott EM, Southon JR, Turney CSM, van der Plicht J. 2013. IntCal13 and Marine13 radiocarbon age calibration curves 0-50,000 years cal BP. Radiocarbon 55 (4). DOI: $10.2458 /$ azujsrc.55.16947.

Rhein M, Kirchner K, Mertens C, Steinfeldt R, Walter M, Fleischmann-W ischnath U. 2005. Transport of South Atlantic water through the passages south of Guadeloupe and across 161N, 2000-2004. Deep-Sea Research I 52:2234-49.

Rivé K, Gaillardet J, Agrinier P, Rad S. 2011. Carbon isotopes in the rivers from the Lesser Antilles: origin of the carbonic acid consumed by weath ering reactions in the Lesser Antilles. Earth Surface Processes and Landforms 38:1020-35.

Robinson LF, Belshaw NS, Henderson GM. 2004. $\mathrm{U}$ and $\mathrm{Th}$ concentrations and isotope ratios in modern carbonates and waters from the Bahamas.

Geochimica et Cosmochimica Acta 68(8):1777-89.

Sanjuan B, Millot R, Brach M, Foucher JC, Roig JY, Baltassat JM. 2005. Geothermal exploration in the Mount Pelee volcano-Morne Rouge and Diamant areas (Martinique, West French Indies) : geochemical data. Proceedings of the World Geothermal Congress, April 2005, Antalaya, Turkey. 12 pp.

Sanjuan B, Brach M. 2015. Geochemical monitoring of the thermal manifestations located near the Bouillante geothermal power plant, in Guadeloupe (FWI). Procedia Earth and Planetary Science 13:25-9.

Schmitt RW, Bogden PS, Dorman CE. 1989. Evaporation minus precipitation and density fluxes for the North Atlantic. Journal of Physical Oceanography 19:1208-21.

Smith TM, Reynolds RW, Peterson TC, Lawrimore J. 2006. Improvements NOAAs historical merged land-ocean temp analysis (1880-2006). Journal of Climate 21:2283-96.

Sprintall J, Tomczak M. 1992. Evidence of the barrier layer in the surface layer of the tropics. Journal of Geophysical Research 97:7305-16.

Stramma L, Schott F. 1999. The mean flow field of the tropical Atlantic Ocean. Deep-Sea Research II 46:279-303.

Stramma L, Rhein M, Brandt P, Dengler M, Böning C, Walter M. 2005. Upper ocean circulation in the western tropical Atlantic in Boreal fall 2000. Deep-Sea Research I 52:221-40.

Stuiver M, Polach P. 1977. Discussion: reporting of ${ }^{14} \mathrm{C}$ data. Radiocarbon 19(3):355-63.

Stuiver M, Braziunas TF. 1993. Modeling atmospheric $14 \mathrm{C}$ influences and $14 \mathrm{C}$ ages of marine samples to 10,000 BC. Radiocarbon 35(1):137-89. Stuiver M, Pearson GW, Braziunas TF. 1986. Radiocarbon age calibration of marine samples 
back to 9000 cal yr BP. Radiocarbon 28(2B): 9801021.

Stuiver M, Reimer PJ, Braziunas TF. 1998. Highprecision radiocarbon age calibration for terres trial and marine samples. Radiocarbon 40 (3):1127-51

Stuiver M, Reimer PJ, Bard E, Beck JW, Burr GS, Hughen KA, Kromer B, McCormac G, van der Plicht J, Spurk M. 1998. Intcal98 radiocarbon age calibration, 24,000-0 cal BP. Radiocarbon 40(3): 1041-83.

Tisnérat-Laborde N, Poupeau JJ, Tannau JF, Paterne M. 2001. Development of a semi-automated system for routine preparation of carbonate sample. Radiocarbon 43(2A):299-304.

Van Oldenborgh GJ, Burgers G. 2005. Searching for decadal variations in ENSO precipitation teleconnections. Geophysical Research Letters 32(15): L15701-10. 11029/12005g1023110.

Wagner AJ, Guilderson TP, Slowey NC, Cole JE. 2009. Pre-bomb surface water radiocarbon of the Gulf of Mexico and Caribbean as recorded in hermatypic corals. Radiocarbon 51(3):947-54.

Weber JN, Woodhead PMJ. 1972. Temperature dependance of oxygen-18 concentration in reef coral carbonates. Journal of Geophysical Research 77:463-73.

Weil-Accardo J, Feuillet N, Jacques E, Deschamps P, Beauducel F, Cabioch G, Tapponnier P, Saurel JM, Galetzka J. 2016. Two hundred thirty years of relative sea level changes due to climate and megathrust tectonics recorded in coral microatolls of Martinique (French West Indies). Journal of Geophysical Research Solid Earth 121. DOI: 10.1002/2015JB012406.

Wilson WD, Johns WE, Molinari RL. 1994. Upper layer circulationin the western tropical North Atlantic Ocean during August 1989. Journal of Geophysical Research 99(22):513-23.

Wils on WD, Johns WE. 1997. Velocity structure and transport in the Windward Islands passages. Deep-Sea Research I 44:487-520.

Xue Y, Smith TM, Reynolds RW. 2000. Interdecadal changes of 30-yr SST normals during 1871-2000. Journal of Climate 16:1601-12.

Yoo JM, Carton JA. 1990. Annual and interannual variation of the freshwater budget in the tropical Atlantic Ocean and the Caribbean Sea. Journal of Physical Oceanography 20:831-45. 